\title{
Effects of the Application of STEM Curriculum Integration Model to Living Technology Teaching on Business School Students' Learning Effectiveness
}

\author{
Sri Gunawan \\ Faculty of Economics \& Business, Universitas Airlangga, Indonesia \\ ORCID: 0000-0002-2687-6786 \\ Chich-Jen Shieh \\ Institutes of Quantitative Economics, Huaqiao University, Quanzhou 362021, Fujian, China \\ ORCID: 0000-0002-6158-1983
}

Received: 4 Jun 2020

Accepted: 7 Sep 2020

\begin{abstract}
Learning area integrated teaching, teaching unit topics and the contents of various subjects with team teaching and cooperative learning to have students learn better integrated concepts, is emphasized domestically. Nevertheless, it is discovered that subject-specific teaching is still used in living technology teaching area. The integration and application of knowledge content learned in classes could enhance the problem solving opportunity.

To effectively achieve research objectives and test research hypotheses, nonequivalent test experimental design is applied to the experimental research in this study. Aiming at 312 business school students of Parahyangan Catholic University (UNPAR), Indonesia, as the experimental objects, the research results are summarized as below. 1. STEM curriculum integration model presents significant effects on learning effect. 2. STEM curriculum integration model shows remarkable effects on learning gain. 3. Living technology teaching reveals notable effects on learning effect. 4. Living technology teaching appears significant effects on learning gain. 5. STEM curriculum integration model integrated living technology teaching presents remarkable effects on learning effect. 6. STEM curriculum integration model integrated living technology teaching shows notable effects on the promotion of learning gain. According to the results to propose suggestions, it is expected to have students analyze problems from more aspects and develop diverse solving strategies to effectively enhance living technology learning effectiveness.
\end{abstract}

Keywords: STEM curriculum, living technology teaching, business school, learning effectiveness

\section{INTRODUCTION}

Education aims to assist people in learning and applying knowledge to solve problems in life and make the life more convenient and comfortable. Students would learn basic knowledge and ability in the beginning. When sufficient learning experience is accumulated, students would integrate the learned knowledge to develop higher level thinking so as to enhance the successful problem solving ability. In this case, being able to integrate and apply knowledge content learned in classes could enhance the problem solving opportunity. Learning area integrated teaching, teaching unit topics and the content of various subjects with team teaching and cooperative learning to have students learn better integrated concepts, is emphasized domestically. However, current living technology teaching still focuses on subject-specific teaching. The knowledge students learned through living technology teaching is fragmented knowledge that students, 
when encountering problems, could not integrate and apply the learned fragmented knowledge. Moreover, some knowledge is disconnected with daily life to result in students' low willingness to learn. As a result, students lose the interests in learning living technology to cause low academic achievement.

STEM curriculum integration model, a teaching method integrating science, technology, engineering, and mathematics, integrates the curriculum objective, content, activity, and evaluation (Barroso, 2020; Changtong, Maneejak, \& Yasri, 2020; Chen \& Chang, 2018; Ha et al., 2020; Hasanah, 2020; Madani, 2020; Ritter, 2017). The application of STEM learning activity could combine science, technology, engineering, and mathematics as well as cultivate students' problem solving ability so that students could make thinking and exploration in the life problem and further design the corresponding solution. The curriculum and teaching integration characteristic of STEM curriculum integration model is consistent to the curriculum integration objective in living technology area that the application of STEM curriculum integration model could develop the curriculum integration characteristic, enhance the opportunity for students connecting theories with real life, as well as induce students' learning motivation and enhance students' understanding of the application of science, technology, mathematics, and engineering in the activity process. The design of curricula with the integrative concept allows students integrating fragmented knowledge learned from various subjects through integrative instructional events. Technology education stresses on students' do-it-yourself to cultivate the creative thinking and problem solving ability in the learning process for the application to daily life. Technology teachers should provide the environment for students learning problem solving ability and offer specific and real problem solutions so that students could enhance the technology problem solving ability through the problem solving process. In this case, STEM curriculum integration model could be applied to guide students generating interests in the discussion of problems in life, efficiently applying the knowledge and skills of science, mathematics, and other subjects to solve problems, as well as proving the learned knowledge in order to achieve the learning-application integration. It is the purpose to integrate living technology into the same learning area. STEM curriculum integration model is therefore applied to the research on the effect of living technology teaching on business school students' learning effectiveness in this study. It is expected to have students learn to analyze problems from more aspects, develop diverse solving strategies, and effectively enhance living technology learning effectiveness.

\section{LITERATURE REVIEW}

Ching et al. (2018) stated that thematic curriculum in curriculum integration was theme centered, without considering disciplinary boundary, and organized knowledge, experience, and activity related to the theme to develop the thematic learning activity. Denning (2017) mentioned that STEM curriculum integration model, as thematic curriculum integration, integrated science, technology, engineering, and mathematics for students learning integrated and complete knowledge and applying what they learned to daily life. Hummell (2018) pointed out STEM curriculum integration model as the disciplinary curriculum integration model that STEM curriculum integration model was the integrated curriculum integrating science, technology, engineering, and mathematics, including the curriculum content and instructional events, for students learning systematic knowledge and cultivating knowledge integration and problem solving ability. Barak and Assal (2018) regarded STEM curriculum integration model as the curriculum integration model integrating scientific exploration, technological method, engineering design, and mathematical calculation, containing the curriculum content and instructional events. Techakosit and Nilsook (2018) explained that "science" stressed on the discussion of "why", to pursue and explore rules of the nature, "technology" emphasized "how to do", to authentically produce tools designed in engineering to facilitate human life, "engineering" aimed to design required tools with scientific discovery, and "mathematics" was the basis of scientific knowledge acquisition and the tool for analysis and statistics. Jackson \& Mohr-Schroeder (2018) pointed out the strong relationship among science, technology, engineering, and mathematics, where science developed depending on technology, tested natural phenomena, laws, and rules, technology aimed to understand the function and structure of various materials in the natural world through science, engineering attempted to design tools required for real life through the scientific discovery, and scientific research needed mathematics as the tool and some mathematical theorems as the basis; a lot of scientific laws aimed to deduce mathematical formula. Donegan-Ritter (2017) proposed that the application of STEM curriculum 
integration model to the curriculum integrative learning of science (nature), technology, engineering, and mathematics could positively affect students' learning attitude and effectiveness. Kale et al. (2018) indicated that students, through STEM curriculum integration model, could more easily comprehend complicated engineering and technology concepts to solve technology and engineering problems with the learned concepts. After the STEM learning activity, So et al. (2019) discovered that students could analyze problems and systematically complete works. Wang and Degol (2017) mentioned that learning activity through STEM curriculum integration model allowed students more logically thinking of problems and systematically completing assignments. The following hypotheses are therefore proposed in this study.

H1: STEM curriculum integration model presents significant effects on learning effect.

H2: STEM curriculum integration model shows remarkable effects on learning gain.

Fan and Yu (2017) defined technology as humans' innovation of action, including general knowledge and methods, to develop the system for solving problems and expanding human ability; technology literature referred to the ability of understanding, using, and managing technology. Lai (2018) mentioned that, since technology literacy was the basic ability of people, technology literacy education should be included in formal curricula. Su and Lin (2018) indicated that domestic living technology curriculum in technology education aimed to cultivate citizens' technology literacy of understanding technology, well applying technology, and evaluating technology so as to adapt to the life in the future technological society. Danielle and Farran (2018) defined living technology as having students learn technology literacy of understanding technology, well applying technology, and evaluating technology through the curriculum practice as well as adapting to the life in the future technological society. English (2017) stated that technology education aimed to cultivate students' technology literacy; technology was composed of knowledge, processing, and system content, where knowledge contained 1 . the essence and evolution of technology, 2 . the relationship among individual, society, culture, and technology, and 3. the concept of technology. Processing covered 1 . the design and development of technology system, 2. the control and characteristics of technology system, 3. the use of technology system, and 4 . the consequence and evaluation after using technology system. Wing (2017) explained that system content included 1. information system, 2. material system, and 3. biological system. Chalmers et al. (2017) regarded learning effectiveness as the measurement of students achieving the learning goal in the learning process. After the learning activity, evaluation was utilized for evaluating the effect in order to understand learners' changes in knowledge, skills, and attitude for the reference of curriculum design or teaching quality improvement. Hsu et al. (2018) further indicated that a person with technology literacy would 1 . solve problems by considering different points of view and systems, 2 . understand various systems covered in technology and emphasize system-oriented methods, 3. manage technology systems with the concepts of science, mathematics, social science, and humanities, 4. clearly recognize proper solutions and predict the result, 5. understand major technology concepts, 6. integrate the characteristics of engineering, art, design, craftsmanship, technique, machine, and social personnel, 7. understand and comprehend the importance of basic technology development, 8. combine inspiration and resources to satisfy human demands and desires, 9 . use and understand various classification systems, 10 . see how the society was invented and innovated, and 11. evaluate the influence and consequence of technology systems. Choi et al. (2017) stated that technology education aimed to cultivate citizens' technology literacy, which contained cognition (technology related knowledge), affection (correlations between technology and society, attitude towards technology handling), and skills (problem solving ability). Accordingly, the following hypotheses are proposed in this study.

H3: Living technology teaching reveals notable effects on learning effect.

H4: Living technology teaching appears significant effects on learning gain.

H5: STEM curriculum integration model integrated living technology teaching presents remarkable effects on the promotion of learning effect.

H6: STEM curriculum integration model integrated living technology teaching shows notable effects on the promotion of learning gain. 
Table 1. Variance analysis of STEM curriculum integration model

\begin{tabular}{lcccc}
\hline variable & & $\mathrm{F}$ & $\mathrm{P}$ & \multicolumn{1}{c}{ Scheffe post hoc } \\
\hline STEM curriculum & learning effect & 21.384 & $0.000^{* *}$ & STEM curriculum integration model $>$ general traditional model \\
\cline { 2 - 5 } integration model & learning gain & 27.552 & $0.000^{* *}$ & STEM curriculum integration model $>$ general traditional model \\
\hline${ }^{*}$ stands for $p<0.05,{ }^{* *}$ for $p<0.01$ & & &
\end{tabular}

\section{METHOD AND SAMPLE}

\section{Operational Definition}

\section{STEM curriculum integration model}

With experimental research, teaching with STEM curriculum integration model (experimental group) and general traditional model (control group) are preceded.

\section{Living technology teaching}

Teaching with living technology teaching (experimental group) and general traditional model (control group) is preceded for the living technology teaching experimental research.

\section{Learning effectiveness}

Referring to Chou (2018), learning effectiveness in this study cover two dimensions.

1. Learning effect -including test performance, schedule completion time, and term performance.

2. Learning gain - containing learning satisfaction, achievement, and preference.

\section{Research Subject and Research Design}

To effectively achieve research objectives and test research hypotheses, nonequivalent test experimental design is utilized for the experimental research in this study. Aiming at business school students of Parahyangan Catholic University (UNPAR), Indonesia, total 312 students, as the experimental objects, are preceded the STEM curriculum integration model integrated living technology teaching $2 \backslash_{2}$ experiment. The experiment is grouped into living technology teaching (living technology teaching, general traditional model) XSTEM curriculum integration model (STEM curriculum integration model, general traditional model) for the 15-week ( 3 hours per week for total 45 hours) experimental teaching.

\section{Analysis Method}

Analysis of variance is used for discussing the effect of STEM curriculum integration model on learning effectiveness, the effect of living technology teaching on learning effectiveness, and the effect of STEM curriculum integration model integrated living technology teaching on learning effectiveness.

\section{ANALYSIS AND RESULT}

\section{Variance Analysis of STEM Curriculum Integration Model to Learning Effectiveness}

According to analysis of variance, the difference of STEM curriculum integration model in learning effect and learning gain is discussed. From Table 1, STEM curriculum integration model and general traditional model appear significant differences in learning effect; STEM curriculum integration model shows remarkably higher learning effect than general traditional model that $\mathrm{H} 1$ is supported. STEM curriculum integration model reveals notably higher learning gain than general traditional model that $\mathrm{H} 2$ is supported. 
Table 2. Variance analysis of living technology teaching

\begin{tabular}{llcll}
\hline variable & & $\mathrm{F}$ & $\mathrm{P}$ & \multicolumn{1}{c}{ Scheffe post hoc } \\
\hline \multirow{2}{*}{$\begin{array}{l}\text { living technology } \\
\text { teaching }\end{array}$} & learning effect & 24.362 & $0.000^{* *}$ & living technology teaching $>$ general traditional model \\
\cline { 2 - 5 } & learning gain & 28.943 & $0.000^{* *}$ & living technology teaching $>$ general traditional model \\
\hline
\end{tabular}

* stands for $p<0.05, * *$ for $p<0.01$

Table 3. Variance analysis of STEM curriculum integration model integrated living technology teaching to learning effectiveness

\begin{tabular}{|c|c|c|c|c|c|c|}
\hline \multirow[t]{2}{*}{ variable } & \multicolumn{3}{|c|}{ learning effect } & \multicolumn{3}{|c|}{ learning gain } \\
\hline & $\mathrm{F}$ & $P$ & Scheffe post hoc & $\mathrm{F}$ & $P$ & Scheffe post hoc \\
\hline $\begin{array}{l}\text { STEM curriculum } \\
\text { integration model }\end{array}$ & 14.336 & $0.000 * *$ & $\begin{array}{c}\text { STEM curriculum integration } \\
\text { model>general traditional } \\
\text { model }\end{array}$ & 17.842 & $0.000 * *$ & $\begin{array}{l}\text { STEM curriculum } \\
\text { integration model>general } \\
\text { traditional model }\end{array}$ \\
\hline $\begin{array}{l}\text { living technology } \\
\text { teaching }\end{array}$ & 23.564 & $0.000 * *$ & $\begin{array}{c}\text { living technology } \\
\text { teaching>general traditional } \\
\text { model }\end{array}$ & 26.418 & $0.000 * *$ & $\begin{array}{l}\text { living technology } \\
\text { teaching>general } \\
\text { traditional model }\end{array}$ \\
\hline $\begin{array}{l}\text { STEM curriculum } \\
\text { integration model*living } \\
\text { technology teaching }\end{array}$ & 37.183 & $0.000 * *$ & $11>21>12>22$ & 41.735 & $0.000 * *$ & $11>12>21>22$ \\
\hline
\end{tabular}

* stands for $\mathrm{p}<0.05, * *$ for $\mathrm{p}<0.01$

\section{Variance of Living Technology Teaching to Learning Effectiveness}

Analysis of variance is applied to discuss the difference of living technology teaching in learning effect and learning gain. From Table 2, living technology teaching and general traditional model present significant differences on learning. Living technology teaching shows higher learning effect than general traditional model that $\mathrm{H} 3$ is supported. Living technology teaching reveals higher learning gain than general traditional model that $\mathrm{H} 4$ is supported.

\section{Effects of STEM Curriculum Integration Model Integrated Living Technology Teaching}

Using analysis of variance for discussing the difference of STEM curriculum integration model integrated living technology teaching in learning effectiveness, two-way analysis of variance is applied to discuss the interaction of STEM curriculum integration model and living technology teaching to test the promotion living technology teaching. From Table 3, STEM curriculum integration model integrated living technology teaching appears the highest learning effect and learning gain that $\mathrm{H} 5$ and $\mathrm{H} 6$ are supported.

\section{CONCLUSION}

The research results show obvious progress in learning effectiveness after applying STEM curriculum integration model to living technology teaching activity. Business school students learn the basic skills of living technology and apply the rules learned in science to practice in the activity process so as to make obvious progress on the learning effectiveness. In the learning activity process of applying STEM curriculum integration model to living technology teaching, business school students, through the do-it-yourself process, absorb and understand science, technology, engineering, and mathematics related knowledge. In addition to promoting the knowledge learning of science and engineering, the learning attitude towards technology and engineering is enhanced, and the learned knowledge and attitude could be applied to the life to enhance business school students' willingness to learn.

\section{SUGGESTION}

According to the research conclusions, the following suggestions are proposed in this study. 
1. The learning activity content in STEM is broad that business school students should have learned the knowledge content before the practice of STEM learning activity and the teaching content should be properly adjusted to avoid bad learning effectiveness.

2. Subject knowledge learning tests should be preceded before the learning activity in order to understand individual student's learning situation. It is suggested that low-performance students should be provided more explanations of the learning content to enhance the understanding of applying relevant rules; highperformance students, on the other hand, could be provided more complicated tasks. Since highperformance students could quickly understand and even familiarize the learning content, further content or requirement could be provided in the learning activity. In this case, low-performance students could understand relevant rules and content through learning activity, and high-performance students could learn more content.

3. For the application of STEM curriculum integration model to living technology teaching activity, mathematics and nature content should be reviewed in the beginning. However, some difficult content might cause opposite effect so that most students' willingness to learn science and mathematics cannot be enhanced. It is suggested to have students make works and then the relative rules are explained to further reinforce students' comprehension of subject related content and concepts.

\section{REFERENCES}

Barak, M., \& Assal, M. (2018). Robotics and STEM learning: students' achievements in assignments according to the P3 Task Taxonomy-practice, problem solving, and projects. International Journal of Technology and Design Education, 28(1), 121-144. https://doi.org/10.1007/s10798-016-9385-9

Chalmers, C., Carter, M. L., Cooper, T., \& Nason, R. (2017). Implementing "big ideas" to advance the teaching and learning of science, technology, engineering, and mathematics (STEM). International Journal of Science and Mathematics Education, 15(1), 25-43. https://doi.org/10.1007/s10763-017-9799-1

Ching, Y.-H., Hsu, Y.-C., \& Baldwin, S. (2018). Developing Computational Thinking with Educational Technologies for Young Learners. TechTrends, 62(6), 563-573. https://doi.org/10.1007/s11528-0180292-7

Choi, J., Lee, Y., \& Lee, E. (2017). Puzzle based algorithm learning for cultivating computational thinking. Wireless Personal Communications, 93(1), 131-145. https://doi.org/10.1007/s11277-016-3679-9

Chou, P.-N. (2018). Skill development and knowledge acquisition cultivated by maker education: Evidence from Arduino-based educational robotics. EURASIA Journal of Mathematics, Science and Technology Education, 14(10), em1600. https://doi.org/10.29333/ejmste/93483

Danielle B. D., \& Farran D. C. (2018). Positive early math experiences for African American boys: Nurturing the next generation of STEAM majors. Young Children, 73(2).

Denning, P. J. (2017). Remaining trouble spots with computational thinking. Communications of the ACM, 60(6), 33-39. https://doi.org/10.1145/2998438

Donegan-Ritter, M. (2017). STEM for ALL Children: Preschool Teachers Supporting Engagement of Children with Special Needs in Physical Science Learning Centers. Young Exceptional Children, 20(1), 3-15. https://doi.org/10.1177/1096250614566541

English, L. D. (2017). Advancing elementary and middle school STEM education. International Journal of Science and Mathematics Education, 15(1), 5-24. https://doi.org/10.1007/s10763-017-9802-x

Fan, S.-C., \& Yu, K.-C. (2017). How an integrative STEM curriculum can benefit students in engineering design practices. International Journal of Technology and Design Education, 27(1), 107-129. https://doi.org/10.1007/s10798-015-9328-x 
Hsu, T.-C., Chang, S.-C., \& Hung, Y.-T. (2018). How to learn and how to teach computational thinking: Suggestions based on a review of the literature. Computers \& Education, 126, 296-310. https://doi.org/10.1016/j.compedu.2018.07.004

Hummell, L. J. D. T. E. (2018). Community connections. Children's Technology and Engineering, 22(3), 12-15.

Jackson, C. D., \& Mohr-Schroeder, M. J. (2018). Increasing Stem Literacy Via an Informal Learning Environment. Journal of STEM Teacher Education, 53(1), 43-52. https://doi.org/10.30707/JSTE53.1Jackson

Kale, U., Akcaoglu, M., Cullen, T., Goh, D., Devine, L., Calvert, N., \& Grise, K. (2018). Computational What? Relating Computational Thinking to Teaching. TechTrends, 62(6), 574-584. https://doi.org/10.1007/s11528-018-0290-9

Lai, C.-S. (2018). Using Inquiry-Based Strategies for Enhancing Students' STEM Education Learning. Journal of Education in Science, Environment and Health, 4(1), 110-117.

So, H. J., Ryoo, D., Park, H., \& Choi, H. (2019). What Constitutes Korean Pre-service Teachers' Competency in STEAM Education: Examining the Multi-functional Structure. The Asia-Pacific Education Researcher, 28(1), 47-61. https://doi.org/10.1007/s40299-018-0410-5

Su, J. M., \& Lin, T. W. (2018). Building a Simulated Blockly-Arduino-Based Programming Learning Tool: A Preliminary Study. In 2018 7th International Congress on Advanced Applied Informatics (IIAI-AAI), Yonago, Tottori, Japan (pp. 378-381). https://doi.org/10.1109/IIAI-AAI.2018.00082

Techakosit, S., \& Nilsook, P. (2018). The Development of STEM Literacy Using the Learning Process of Scientific Imagineering through AR. International Journal of Emerging Technologies in Learning (iJET), 13(1), 230-238. https://doi.org/10.3991/ijet.v13i01.7664

Wang, M.-T., \& Degol, J. L. (2017). Gender gap in science, technology, engineering, and mathematics (STEM): Current knowledge, implications for practice, policy, and future directions. Educational Psychology Review, 29(1), 119-140. https://doi.org/10.1007/s10648-015-9355-x

Wing, J. M. (2017). Computational thinking's influence on research and education for all. Italian Journal of Educational Technology, 25(2), 7-14. https://doi.org/10.17471/2499-4324/922

Correspondence: Sri Gunawan, Faculty of Economics \& Business, Universitas Airlangga, Indonesia. E-mail: sgunawan@feb.unair.ac.id 